\title{
Peningkatan Hasil Belajar Matematika Materi Pecahan Kelas III Menggunakan Metode Problem Based Learning
}

\section{Ratih Rintan Susandra}

Universitas Sebelas Maret

rintansusandra@gmail.com

\section{Article History}

received 30/4/2021

\begin{abstract}
Learning outcomes are abilities obtained by students through learning activities. In realizing quality learning, appropriate learning methods are needed. The purpose of this study was to improve learning outcomes of fractional mathematics using the Problem Based Learning method for third grade elementary school students. This research uses Classroom Action Research (CAR) with three cycles. Each cycle in this study went through the stages of planning, implementation, observation, and reflection. In the first cycle it is 54.3, in the second cycle it is 74 , and in the third cycle it is 83 . The affective learning outcomes of students' tolerance attitude in the first cycle is 2.7, the second cycle is 3 , and the third cycle is 3.2. Furthermore, the attitude of cooperation in the first cycle is 2.6, the second cycle is 2.8, and the third cycle is 3.4. Meanwhile, for psychomotor learning outcomes, the skills to analyze fraction problems in the first cycle are 2, 6, the second cycle is 2.9, and in the third cycle is 3.3. This shows that the Problem Based Learning method can improve the learning outcomes of class III students with fractions.
\end{abstract}

Keywords: Learning Outcomes, Problem Based Learning, Fractions Materi

\begin{abstract}
Abstrak
Hasil belajar merupakan kemampuan yang diperoleh peserta didik melalui kegiatan belajar. Dalam mewujudkan pembelajaran yang berkualitas diperlukan metode belajar yang tepat. Tujuan penelitian ini adalah untuk meningkatkan hasil belajar matematika materi pecahan menggunakan metode Problem Based Learning bagi peserta didik kelas III SD. Peneltian ini menggunakan Penelitian Tindakan Kelas (PTK) dengan tiga siklus. Setiap siklus dalam penelitian ini melalui tahapan perencanaan, pelaksanaan, observasi, dan refleksi. Pada siklus I sebesar 54,3, pada siklus II sebesar 74, dan pada siklus III sebesar 83. Hasil belajar afektif sikap toleransi peserta didik pada siklus I sebesar 2,7, siklus II sebesar 3, dan siklus III sebesar 3,2. Selanjutnya untuk sikap kerja sama pada siklus I sebesar 2,6, siklus II memiliki sebesar 2,8, dan siklus III sebesar 3,4. Sedangkan untuk hasil belajar psikomotorik Keterampilan menganalisis masalah pecahan pada siklus I sebesar 2, 6, siklus II sebesar 2,9, dan pada siklus III sebesar 3,3. Hal ini menujukkan bahwa metode Problem Based Learning dapat meningkatkan hasil belajar peserta didik kelas III materi pecahan.
\end{abstract}

Kata kunci: Hasil Belajar, Problem Based Learning, Materi Pecahan 


\section{PENDAHULUAN}

Pendidikan merupakan kunci pembuka kemajuan suatu bangsa, tanpa adanya pendidikan suatu bangsa tidak akan memiliki pondasi yang kuat dan daya saing. Pendidikan yang baik berasal dari pembelajaran berkualitas. Dalam mewujudkan pembelajaran berkualitas diperlukan keselarasan antara kurikulum, sekolah, guru, peserta didik, dan orang tua atau masyarakat. Enam komponen tersebut sangat berpengaruh terhadap keberhasilan suatu pembelajaran. Maka diperlukan kesatuan visi dan misi dalam melaksanakan pembelajaran yang berkualitas. Meskipun enam komponen tersebut memiliki peran penting, namun peran guru jauh lebih mendominasi terhadap keberhasilan suatu pembelajaran. Hal ini dikarenakan, guru sebagai penentu arah sekaligus perancang dan pelaksana pembelajaran. Sehingga guru harus memiliki strategi dalam merancang pembelajaran termasuk memilih model, pendekatan, metode, teknik, media dan penilaian pembelajaran. Namun kenyataanya, masih banyak guru yang belum dapat memilih dan menggunakan model, pendekatan, metode, teknik, media dan penilaian pembelajaran secara tepat. Hal ini tentu berdampak pada keberhasilan peserta didik dalam belajar. Hasil-hasil belajar merupakan pola-pola dalam perbuatan, nilai-nilai, pengertian-pengertian, dan sikapsikap , serta apresepsi dan abilitas yang dilihat dari peserta didik. Hamalik (2003) dalam Jihad dan Haris (2012: 15). Benjamin S dalam Kurniawan (2014:10-11) berpandangan, terdapat tiga ranah (domain) hasil belajar yaitu kognitif, afektif, dan psikomotorik. Kognitif berhubungan dengan pengetahuan, afektif berhubungan dengan sikap dan psikomotorik berhubungan dengan ketrampilan

Salah satu permasalahan pembelajaran saat ini yaitu muatan pelajaran matematika. Sering kali matematika dianggap sebagai momok oleh peserta didik. Rumitnya memahami rumus dan penyelesaian soal merupakan sebuah beban bagi peserta didik, ditambah lagi guru belum menggunakan metode dan media yang tepat dalam pembelajaran. Hal ini ditunjukkan laporan Programme for International Student Asessment (PISA) pada 3 Desember 2019, skor matematika Indonesia menempati peringkat 66 dari 79 negara yang berpartispasi (https://www.liputan6.com/global/read/4126480/skor-terbaru-pisa-indonesia-merosotdi-bidang-membaca-sains-dan-matematika). Artinya pembelajaran matematika di Indonesia belum berhasil secara maksimal.

Hasil observasi yang dilakukan peneliti pada tanggal 21 November 2020, menujukkan permasalahan yang dihadapi guru dalam mengajarkan muatan pelajaran matematika materi pecahan di kelas III. Dilihat dari hasil belajar peserta didik belum memenuhi KKM pada saat penilaian ulangan harian maupun penilaian semester. Melalui pengamatan dan wawancara peneliti menemukan masalah diantaranya: 1) rendahnya hasil belajar peserta didik. 2) kurangnya minat dan motivasi belajar peserta didik. 3) belum terciptanya pembelajaran yang menyenangkan. 4) guru belum menemukan metode dan media yang tepat untuk pembelajaran dan masih menggunakan merode konvensional. Salah satu metode pembelajaran yang dapat digunakan guru dalam meningkatkan hasil belajar peserta didik pada matematika materi pecahan yaitu Problem Based Learning (PBL). Metode ini mengemas pembelajaran dengan memberikan peserta didik sebuah permasalahan untuk diselesaikan, sehingga peserta didik dapat menemukan solusi pemecahan masalah dan diasosiasikan menjadi sebuah konsep. Pelakasanaan model Problem Based Learning terdiri dari 5 tahap proses. Penelitian penggunaan metode Problem Based Learning (PBL) pernah dilakukan oleh Eva Asi Godang Samosir dan Taruli Marito Silalahi dengan judul penelitian "UPAYA MENINGKATKAN HASIL BELAJAR MATEMATIKA MATERI PECAHAN MENGGUNAKAN MODEL PEMBELAJARAN PROBLEM BASED LEARNINGDI KELAS III SD NEGERI 066045 MEDAN HELVETIA T.A 2018/2019" (Vol. 1, No. 2, February-August 2019 ISSN 2622-8823). Penelitian tersebut memiliki hasil yaitu penerapan model Problem Based Learning dapat 
meningkatkan hasil belajar siswa kelas III-A SD Negeri 066045 Medan Helvetia mata pelajaran matematika materi pecahan. Hal tersebut dibuktikan berdasarkan tes prasiklus dengan nilai rata-rata 63,5 ketuntasan klasikal $30 \%$, siklus I nilai rata-rata 71,5 ketuntasan klasikal 55\%, dan terakhir siklus II nilai ratarata $88 \%$ ketuntasan klasikal $100 \%$. Merujuk masalah yang telah dipaparkan perlu adanya solusi untuk mengatasinya. Diduga oleh peneliti metode Problem Based Learning berbasis permainan dapat menjadi solusi. Harapannya dengan menggunakan metode Problem Based Learning (PBL) berbasis permainan dapat meningkatkan hasil belajar peserta didik pada matematika materi pecahan. Guna mengetahui bagaimana peningkatan hasil belajar kognitif peserta didik maka dari itu perlu diadakan penelitian dengan judul "Peningkatan Hasil Belajar Matematika Materi Pecahan Menggunakan Metode Problem Based Learning". Penelitian ini bertujuan untuk mengetahui proses peningkatan hasil belajar matematika materi pecahan menggunakan metode Problem Based Learning berbasis permainan matematika bagi peserta didik kelas III SDN 3 Nglanji Boyolali.

\section{METODE}

Penelitian dilakukan di SD N 3 Nglanji Kecamatan Kemusu, Kabupaten Boyolali. Subjek dalam penelitian ini adalah peserta didik kelas III. Penelitian yang dilakukan merupakan Penelitian Tindakan Kelas (PTK) dengan 3 siklus. Menurut Kurt Lewin dalam Kunandar (2011: 42) Setiap siklusnya memiliki tahapan yaitu perencanaan, pelaksanaan Tindakan, observasi, dan refleksi. Data pada penelitian ini berupa informasi tentang hasil belajar peserta didik dalam pembelajaran tematik integratif matematika materi pecahan. Data penelitian ini dikumpulkan dari berbagai sumber yaitu Informan atau nara sumber sebagai subjek yang akan dimintai innformasi berkaitan dengan hasil belajar kognitif peserta didik. Informan pada penelitian ini adalah peserta didik dan guru Tempat dan peristiwa berlangsungnya aktivitas pembelajaran matematika materi pecahan kelas III, Dokumen atau arsip yaitu dapat berupa Kurikulum, Rencana Pelaksanaan Pembelajaran (RPP), Hasil Belajar Peserta didik, dan buku penilaian. Teknik pengumpulan data pada penelitian ini yaitu menggunakan tes, Kajian dokumen, dan wawancara. Analisis data yang digunakan merupakan analisis data kualitatif dan kuantitatif, menurut Laksono dan Siswono (2018: 73-74) terdapat beberapa tahapan dalam analisis data kualitatif dan kuantitatif yaitu reduksi data, paparan data dan penyimpulan. Analisis Data Kuantitatif Data kuantitatif diperoleh dari hasil tes yang dikerjakan peserta didik pada siklus I, siklus II dan siklus III dengan rumus:

$$
S=\frac{\sum B \times 100}{\mathrm{~N}}
$$

\section{HASIL DAN PEMBAHASAN}

Pembelajaran materi pecahan matematika menerapkan metode Problem Based Learning karena metode ini dirasa tepat oleh guru untuk meningkatkam hasil belajar kognitif, afektif dan psikomotorik peserta didik. Dengan memecahkan sebuah permasalahan secara kelompok, hal ini dapat merangsang kemampuan peserta didik dalam berpikir kritis, menggunakan maupun membangun struktur kognitif dalam menentukan sebuah solusi dan mengelola diri untuk bersikap jujur, toleransi serta kerjasama demi tercapainya keberhasilan kelompok. Pembelajaran dilaksanakan berdasarkan tahapan metode Problem Based Learning mulai dari orientasi masalah hingga evaluasi hasil peneyelidikan. Seperti halnya yang disampaikan oleh Trianto (2007 : 68), Metode Problem Based Learning memiliki tahapan yang harus dilakukan pada saat pembelajaran berlangsung. Adapun tahapan Problem Based Learning terdiri 
dari 5 tahap yaitu 1) tahap pertama proses orientasi peserta didik pada masalah. Pada tahap ini guru menjelaskan tujuan pembelajaran, menjelaskan logistik yang diperlukan, memotivasi peserta didik untuk terlibat dalam aktivitas pemecahan masalah, dan mengajukan masalah. 2) Tahap kedua, mengorganisasi peserta didik. Pada tahap ini guru membagi peserta didik kedalam kelompok, membantu peserta didika mendefinisikan dan mengorganisasikan tugas belajar yang berhubungan dengan masalah. 3) Tahap ketiga, membimbing penyeledikan individu maupun kelompok pada tahap ini guru mendorong peserta didik untuk mengumpulkan informasi yang dibutuhkan, melaksanakan eksperimen dan penyelidikan untuk mendapatkan penjelasan dan pemecahan masalah. 4) Tahap keempat, mengembangkan dan menyajikan hasil. Pada tahap ini guru membantu peserta didik dalam merencanakan dan menyiakan laporan, dokumentasu, atau model dan membantu mereka berbagi tugas dengan sesama temannya. 4) Tahap kelima, menganalisis dan mengevaluasi proses dan hasil pemecahan masalah. Pada tahap ini guru membantu peserta didik untuk melakukan refleksi atau evaluasi terhadap proses dan hasil penyelidikan yang mereka lakukan. Peningkatan hasil belajar peserta didik pada materi pecahan dengan menggunakan metode Problem Based Learningdapat ditunjukkan dengan hasil yang diperoleh peserta didik setelah mengerjakan tes tertulis, penilaian sikap dan keterampilan seperti yang ada di dalam tabel di bawah ini.

Tabel 1. Rekapitulasi Hasil Belajar Kognitif Peserta Didik Pada Pembelajaran Materi Pecahan

\begin{tabular}{lllll}
\hline Keterangan & Tes Awal & Siklus I & Siklus II & Siklus III \\
\hline Nilai Terendah & 20 & 20 & 40 & 55 \\
Nilai Tertinggi & 70 & 70 & 90 & 95 \\
Rata-rata Nilai & 42,7 & 54,3 & 74 & 83 \\
Tuntas KKM & 1 & 2 & 11 & 14 \\
\hline
\end{tabular}

Tabel di atas menunjukkan bahwa hasil belajar kognitif pada pra tindakan memiliki rata - rata 42,7, pada siklus I memiliki rata - rata 54,3, pada siklus II memiliki rata - rata 74 , dan pada siklus III memiliki rata - rata 83. Sehingga terlihat jelas bahwa terdapat peningkatan hasil belajar kognitif peserta didik setelah dilakukannya tindakan menggunakan metode Problem Based Learning.

Tabel 2. Rekapitulasi Hasil Belajar Afektif Peserta Didik Pada Pembelajaran Materi Pecahan

\begin{tabular}{lllllllll}
\hline \multirow{2}{*}{ Keterangan } & \multicolumn{2}{l}{ Tes Awal } & \multicolumn{2}{l}{ Siklus I } & \multicolumn{2}{c}{ Siklus II } & \multicolumn{2}{c}{ Siklus III } \\
\cline { 2 - 10 } & $\begin{array}{llllll}\text { Toler } \\
\text { ansi }\end{array}$ & $\begin{array}{l}\text { Kerjas } \\
\text { ama }\end{array}$ & $\begin{array}{l}\text { Toler } \\
\text { ansi }\end{array}$ & $\begin{array}{l}\text { Kerjas } \\
\text { ama }\end{array}$ & $\begin{array}{l}\text { Toler } \\
\text { ansi }\end{array}$ & $\begin{array}{l}\text { Kerjas } \\
\text { ama }\end{array}$ & $\begin{array}{l}\text { Toler } \\
\text { ansi }\end{array}$ & $\begin{array}{l}\text { Kerjas } \\
\text { ama }\end{array}$ \\
\hline Nilai Terendah & 2 & 1 & 2 & 1 & 2 & 1 & 3 & 2 \\
Nilai Tertinggi & 3 & 3 & 4 & 4 & 4 & 2 & 4 & 4 \\
Rata-rata Nilai & 2,6 & 2,5 & 2,7 & 2,6 & 3 & 2,8 & 3,2 & 3,4 \\
\hline
\end{tabular}

Hasil belajar afektif sikap toleransi peserta didik pada pratindakan memiliki dengan rata-rata 2,6 untuk sikap, pada siklus I memiliki rata - rata 2,7, pada siklus II memiliki rata-rata 3 , dan pada siklus III memiliki rata - rata 3,2. Selanjutnya untuk sikap kerja sama pada pratindakan memiliki rata - rata 2,5 , pada siklus I memiliki rata - rata 2,6, pada siklus II memiliki rata - rata 2,8, dan pada siklus III memiliki rata - rata 3,4. Hal ini menunjukkan adanya peningkatan hasil belajar afektif setelah dilakukan tindakan hingga siklus III. 
Volume 9 Nomor 1 Tahun 2021

Tabel 3. Rekapitulasi Hasil Belajar Psikomotorik Peserta Didik Pada Pembelajaran Materi Pecahan

\begin{tabular}{|c|c|c|c|c|c|c|c|c|}
\hline \multirow[b]{2}{*}{ Keterangan } & \multicolumn{2}{|c|}{ Tes Awal } & \multicolumn{2}{|c|}{ Siklus I } & \multicolumn{2}{|c|}{ Siklus II } & \multicolumn{2}{|c|}{ Siklus III } \\
\hline & $\begin{array}{l}\text { Peta } \\
\text { pikiran }\end{array}$ & $\begin{array}{l}\text { Analisi } \\
\text { s } \\
\text { masal } \\
\text { ah } \\
\text { pecah } \\
\text { an }\end{array}$ & $\begin{array}{l}\text { Peta } \\
\text { pikiran }\end{array}$ & $\begin{array}{l}\text { Analisi } \\
\text { s } \\
\text { masal } \\
\text { ah } \\
\text { pecah } \\
\text { an }\end{array}$ & $\begin{array}{l}\text { Peta } \\
\text { pikiran }\end{array}$ & $\begin{array}{l}\text { Analisi } \\
\text { s } \\
\text { masal } \\
\text { ah } \\
\text { pecah } \\
\text { an }\end{array}$ & karya & $\begin{array}{l}\text { Analisi } \\
\text { s } \\
\text { masal } \\
\text { ah } \\
\text { pecah } \\
\text { an }\end{array}$ \\
\hline Nilai Terendah & 2 & 1 & 2 & 1 & 2 & 2 & 3 & 2 \\
\hline Nilai Tertinggi & 3 & 3 & 4 & 4 & 4 & 4 & 4 & 4 \\
\hline Rata-rata Nilai & 2,6 & 2,5 & 2,8 & 2,7 & 3,2 & 2,9 & 3,5 & 3,3 \\
\hline
\end{tabular}

Tabel 3 menunjukkan hasil belajar psikomotorik Keterampilan menganalisis masalah pecahan pada pra tindakan memiliki rata - rata 2,5, pada siklus I memiliki rata - rata 2, 6, pada siklus II memiliki rata - rata 2,9, dan pada siklus III memiliki rata - rata 3,3. Sehingga hal ini terlihat jelas bahwa terdapat peningkatan hasil belajar psikomotorik setelah dilakukannya tindakan dengan metode Problem Based Learning. Untuk ketrampilan membuat peta pikiran pada pra Tindakan memiliki rata - rata 2,6, pada siklus I memiliki rata - rata 2,9, pada siklus II memiliki rata - rata 3,2 , pada siklus III memiliki rata - rata 3,5.

Hasil penelitian yang sudah dipaparkan di atas menujukkan bahwa hasil belajar materi pecahan kelas III meningkat setelah menggunakan metode Problem Based Learning. Hal ini sesuai dengan penelitian sebelumnya oleh Ansariyah (2017) yang membuktikan bahwa metode Problem Based Learning dapat meningkatkan hasil belajar peserta didik pada materi pecahan. Peningkatan hasil belajar peserta didik pada materi pecahan dipengaruhi oleh beberapa hal diantaranya minat belajar, keaktifan, pemahaman konsep, sikap toleransi dan Kerjasama peserta didik. Minat belajar dan beberapa hal tersebut dapat dimiliki peserta didik dengan baik pada saat mengikuti pembelajaran materi pecahan dengan menggunakan metode Problem Based Learning. Sehingga hal ini menunjukkan bahwa metode Problem Based Learning memang tepat digunakan untuk pembelajaran materi pecahan kelas III semester 2. Metode ini menuntut peserta didik untuk berpikir kritis dalam menentukan sebuah solusi permasalahan. Secara tidak langsung peserta didik akan menggunakan struktur kognitif yang sudah ada untuk memecahkan masalah dan mendapatkan sebuah konsep yang baru melalui pemecahan masalah secara berkelompok. Selain itu peserta didik dapat mengembangkan kemandirian, tanggung jawab, sikap toleransi dan kerja sama dalam kelompok saat melaksanakan tahapan Problem Based Learning. Hal ini seperti yang kemukakan oleh Amir (2009 : 27) tentang manfaat metode Problem Based Learning yaitu 1) Menjadi lebih ingat dan meningkatkan pemahamannya atas materi ajar, apabila pengetahuan didapatkan lebih dekat dengan konteks praktiknya, maka kita akan lebih ingat. Pemahaman juga demikian. Dengan konteks yang dekat, dan sekaligus melakukan deep learning (karena banyak mengajukan pertanyaan menyelidik) buka surface learning (yang sekadar hafal saja), maka pemelajar yang seperti ini apa pun bidang yang mereka pelajari. 2) Meningkatkan fokus pada pengetahuan yang relevan dengan kemampuan pendidik membangun masalah yang konteks praktik, siswa bisa merasakan lebih baik konteks operasinya di lapangan. 3) Mondorong untuk berfikir, dengan proses yang mendorong siswa untuk mempertanyakan, kritis, reflektif, maka manfaat ini bisa berpeluang terjadi. 
4) Membangun kecakapan belajar (life-long learning skills) Siswa perlu dibiasakan untuk mampu belajar terus-menerus. Mereka harus mengembangkan bagaimana kemampuan untuk belajar (learn how to learng). 5) Memotivasi pembelajar, PBL mempunyai peluang untuk membangkitkan minat dari diri siswa, karena peserta didik memecahkan masalah yang konteks dengan kehidupan sehari - hari.

Penggunaan metode Problem Based Learning pada pembelajaran materi pecahan kelas III dapat meningkatkan hasil belajar peserta didik. Dengan data dari 15 peserta didik terdapat sebanyak 14 peserta didik sudah mencapai KKM, dan 1 peserta didik belum mencapai KKM. Peserta didik yang belum mencapai KKM diduga mengalami kesulitan belajar dan kebutuhan khusus. Hal ini diamati oleh peneliti pada saat pembelajaran berlangsung dan berdasarkan infomasi dari guru kelas. Untuk mengatasi 1 peserta didik yang belum mencapai KKM maka diperlukan pendampingan khusus oleh peneliti dan guru.

\section{SIMPULAN}

Pembelajaran matematika materi pecahan dengan metode Problem Based Learning dapat menumbuhkan minat belajar, keaktifan, pemahaman konsep, dan sikap toleransi serta kerjasama pada diri peserta. Berdasarkan hasil penelitian yang dilakukan oleh peneliti selama 3 siklus, pembelajaran materi pecahan dengan menggunakan metode Problem Based Learning dapat meningkatkan hasil belajar pesert didik. Hal ini dapat ditunjukkan dengan peningkatan rata - rata hasil belajar peserta didik baik hasil belajar kognitif, afektif dan psikomotorik. Pada pra tindakan rata - rata hasil belajar kognitif peserta didik yaitu 42,7, pada siklus I sebesar 54,3, pada siklus II sebesar 74, dan pada siklus III sebesar 83. Hasil belajar afektif sikap toleransi peserta didik pada pra Tindakan memiliki rata-rata 2,6, pada siklus I sebesar 2,7, siklus II sebesar 3 , dan siklus III sebesar 3,2. Selanjutnya untuk sikap kerja sama pada pra tindakan memiliki rata - rata 2,5, siklus I sebesar 2,6, siklus II memiliki sebesar 2,8, dan siklus III sebesar 3,4. Sedangkan untuk hasil belajar psikomotorik Keterampilan menganalisis masalah pecahan pada pra Tindakan memiliki rata - rata 2,5, siklus I sebesar 2, 6, siklus II sebesar 2,9, dan pada siklus III sebesar 3,3.

\section{DAFTAR PUSTAKA}

Amir, M. T. (2009). Inovasi Pendidikan Melalui Problem Based Learning. Jakarta: Media Grup.

Ansariyah. (2017). Meningkatkan Aktivitas Dan Hasil Belajar Matematika Pada Materi Pecahan Melalui Metode Pembelajaran Problem Based Learning(Pbl) Pada Siswa Kelas III Min 6 Susoh Aceh Barat Daya Tahun Pelajaran 2016/2017. Jurnal Pendidikan

Jihad dan Haris. (2012). Evaluasi Pembelajaran . Yogyakarta : Multi Pressindo

Laksono, Kisyani dan Siswono, Tatag. (2018). Penelitian Tindakan Kelas. Bandung: Remaja Rosdakarya.

Kasbolah, K. 1(999). Penelitian Tindakan Kelas. Jakarta : Dekdikbud.

Kunandar. (2011). Langkah Mudah Penelitian Tindakan Kelas Sebagai Pengembang Profesi Guru. Jakarta: PT Raja Grafindo Persada.

Kurnia, Tommy. (2019). Skor Terbaru PISA Indonesia Merosot di Bidang Membaca, Sains, dan Matematika. https://www.liputan6.com/global/read/4126480/skorterbaru-pisa-indonesia-merosot-di-bidang-membaca-sains-dan-matematika (diakses pada 29 Desember 2020, pukul 20:07)

Kurniawan, Deni. (2014). Pembelajaran Terpadu TEMATIK (Teori, Praktik, dan Penilaian). Bandung: Alfabeta.

Samani, Muchlas. (2014). Belajar dan Pembelajaran. Bandung: Remaja Rosdakarya.

Samosir, Godang. (2019). Upaya Meningkatkan Hasil Belajar Matematika Materi Pecahan Menggunakan Model Pembelajaran Problem Based LearningDi Kelas lii 
Volume 9 Nomor 1 Tahun 2021

Sd Negeri 066045 Medan Helvetia T.A 2018/2019. Jurnal Pendidikan : Vol. 1, No. 2, February-August 2019 ISSN 2622-8823.

Trianto. (2007). Model Model Pembelajaran Inovatif Berorientasi Kontruktivisme. Jakarta : Prestasi Pustaka 